\title{
Foreign Direct Investment, Intellectual Property Rights and Economic Growth: A Panel Study for Arabic Countries
}

\author{
Hadhek Zouhaier ${ }^{1} \&$ Mrad Fatma ${ }^{2}$ \\ ${ }^{1}$ Higher Institute of Management (ISG) of Gabès, University of Gabès, Tunisia \\ ${ }^{2}$ Faculty of Economics and Management scineces of Sousse, University of Sousse, Tunisia \\ Correspondence: Hadhek Zouhaier, Higher institute of management, ISG of Gabès, University of Gabès, Tunisia. \\ Tel: 216-97-388-013. E-mail: hzouhair2000@yahoo.fr
}

Received: January 21, 2014

Accepted: February 22, 2014

Online Published: April 25, 2014

doi:10.5539/ijef.v6n5p56

URL: http://dx.doi.org/10.5539/ijef.v6n5p56

\begin{abstract}
The main purpose of this paper is to examine the role of the protection of intellectual property rights (IPR) in Arab countries to encourage developed countries to transfer their technologies to Arab countries and its impact on economic growth using panel data of seven Arab countries in terms of patent protection, foreign direct investment (FDI) and the specific characteristics of each country for the period 1970-2011. The results of our simultaneous equations model suggest that FDI affects negatively growth in total factor productivity (TFP). They show that IPR protection stimulates TFP growth by attracting FDI and technology flows.
\end{abstract}

Keywords: protection of intellectual property rights, foreign direct investment, economic growth

\section{Introduction}

The potential role of IPR in technology transfer through FDI is a relatively new topic of research. Few theoretical studies have examined the nature of the relationship between IPR protection and FDI. They show a strengthening of IPR improved incentives for innovation in developed countries if this building would increase FDI (Lai, 1998). Some empirical studies have come to highlight a significant relationship between IPR protection and FDI (Lee \& Mansfield, 1996; Maskus, 1998; Park \& Lippoldt, 2008).

The main purpose of this work is to study the role of IPR in technology transfer through FDI and economic growth in the case of Arab countries. Note that the relationship between IPR protection, FDI and economic growth are still poorly understood, particularly in the case of developing countries. On the one hand, some studies are conducted around the links between FDI and economic growth in a host country by ignoring the role of IPR protection (Blomstrom et al., 1994; Borensztein et al., 1998; Balasubramanyam et al., 1999; Xu, 2000; Lee, 2001). On the other hand, a limited number of studies have examined the relationship between IPR protection and economic growth while ignoring the role of FDI (Gould \& Gruben, 1996; Park \& Ginarte, 1997; $\mathrm{Xu} \&$ Chiang, 2005; Falvey \& Foster, 2006). The results of these studies are ambiguous.

Compared to the literature, this work aims to estimate the effects of IPRs on technology transfer through FDI and economic growth in the case of Arab countries using a two-equation model. Studies on the effects of IPR protection using a two-equation model are sparse and inconclusive in the case of developing countries. Park and Ginarte (1997) investigated the role of IPR protection in the accumulation of factors of production and economic growth. $\mathrm{Xu}$ and Chiang (2005) studied the role of IPR protection in technology transfer through the flow of foreign patents and economic growth.

To investigate the relationship between the IPR protection and economic growth on the one hand and between the IPR protection and FDI on the other hand, we will proceed as part of this work, a two-equation panel model for a sample of seven Arabic countries over the period 1970-2011.

The rest of the paper is organized as follow. In section 1, we review the empirical literature on the relationship between the IPR protection and economic performance. Section 2 discusses the empirical set-up of our model, the data employed and the results. In section 3, we summarize our results and provide concluding remarks.

\section{Review of the Empirical Literature}

While theorists are still far from complete work on the issue that focuses on channels through which the IPR 
protection influence and can influence the economic sphere.

Several empirical studies have emerged, with the aim to provide additional arguments to the controversial association between IPR protection and economic performances. In what follows we will, move to a review of the empirical literature on the subject.

\subsection{Technology Transfer Related to FDI and Economic Growth}

The new growth theory has highlighted the key role of technology transfer through FDI in accelerating growth in developing countries. More particularly, according to the model of Borensztein et al. (1998), the introduction of capital goods accounted for by the presence of the flow of FDI leads to technical progress, the source of economic growth. According to this model, FDI is a means of transmission of knowledge production and dissemination of new innovations and new methods of production, thereby lowering costs borne by domestic producers.

However, according to some studies, the volume of broadcast technology in the host country is generally influenced by its absorption capacity. Indeed, the role of FDI in improving productivity will be more important in a country with higher absorption capacity where local firms are able to absorb new technologies transferred and apply new techniques acquired production.

A first group of studies consider that the contribution of FDI to growth is enhanced by the level of development of the host country (Blomstrom et al., 1998; De Mello, 1999). They show that the effect of FDI is more important for developing countries with high incomes. In other words, there is a minimum level of income below which FDI has no significant effect on growth.

A second group of empirical studies show that FDI contributes to the economic growth of developing countries that if they have a minimum stock of human capital that enables them to use the technology diffused ( Borensztein et al., 1998; Xu, 2000; Lee, 2001). Indeed, they show that for developing countries, a minimum threshold of human capital is required to benefit from FDI and more accurate way to benefit from foreign technology. However, the majority of developing countries have not reached this threshold.

A third group of empirical studies indicate that the presence of a sufficient degree of openness in the host country is a key factor for successful technology transfer and diffusion favored by FDI techniques. In other words, trade policies in the host countries appear to affect the magnitude of the induced growth of FDI since there is a link between trade regimes and economic growth in the long term (Balasubramanyam et al., 1996; De Mello, 1997).

\subsection{The Relationship between IPR Protection and Economic Growth}

A limited number of empirical studies have examined the relationship between IPR protection and economic growth. Their results are mixed.

According to Gould and Gruben (1996), IPR protection stimulates economic growth if it is accompanied by a policy of trade liberalization. The authors have demonstrated a positive and significant effect of IPR protection on economic growth for all developed countries and developing countries. More specifically speaking, the authors show that the effect of IPR protection is more important for relatively open economies. By encouraging initiatives to innovate, IPR protection may influence the growth of an open country.

According to Park and Ginarte (1997), IPR affect economic growth indirectly by stimulating the accumulation of factors of production such as physical capital and R\&D capital. In fact, Park and Ginarte (1997) indicate that the IPR indicator has a direct and non-significant effect on the GDP per capita growth rate for a sample of developed and developing countries over the period 1960-1990. Their results show that IPR protection encourages the research sector to invest and take risks. This consequently stimulates economic growth.

The empirical results of Xu and Chiang (2005) show that IPR protection affects economic growth indirectly by attracting flows of foreign patents. At first, the authors considered the inflows of foreign patents as a determinant, among others, of the rate of growth of total factor productivity (TFP) of a country. In a second step, the authors consider the system of IPR protection and trade openness as determinants of inflows of foreign patents in a country to the extent that the decisions of foreign inventors to patent in a country are associated with their commercial activities in the country.

According to other studies, IPR protection stimulates economic growth of a country based on a certain level of development. The effect of IPR protection on the growth rate of GDP per capita is positive and statistically significant only for developed countries (Thompson \& Rushing, 1996).

Other studies found that the relationship between IPR protection and economic growth is nonlinear. It depends upon the level of development of a country as well as the structure of its economic defined by the share of 
manufacturing value added in GDP and the degree of openness ( Falvey et al., 2004; Falvey \& Foster, 2006).

\subsection{The Relationship between IPR Protection and FDI}

According to the theory, a strengthening of IPR protection in the South would improve the incentives for innovation in the North if the transmission channel of production from North to South is the FDI. Strengthening IPR protection is interpreted as incentive given by the South to encourage Northern FDI (Lai, 1998).

Specifically, Lai (1998) indicates that the effects of strengthening IPR protection in the countries of the South on the pace of innovation, on the transfer of production and on relative wages depend on the transfer channel production North to South.If the transfer channel production is imitation, stronger IPR protection in the South decreases the rate of innovation, the rate of product transfer and the relative wage in the South. The effects go in the opposite direction if the transfer of the production takes place through FDI. If the transfer of production from North to South is via imitation, stronger IPR protection has two opposing effects. On the one hand, it reduces the rate of imitation in the South and extends the duration of a monopoly of each innovator in the North. That's increases the returns to innovation. On the other hand, the increase in production in the North stimulates the demand for Northern labor and increases the relative wage. Therefore, the cost of innovation increases thus reducing the profit earned by each innovator. Ultimately, the second effect outweighs the first and the rate of innovation declines.

If the transfer of production from North to South is via FDI, strengthening IPR protection in the South has the effect of increasing the rate of innovation in the North and to encourage the transfer of Production from North to South. Indeed, following the increase in monopoly power, the returns to innovation increases without increasing costs. Northern firms will locate in the South, which reduces the demand for labor in the North as well as costs.

Empirically, some studies show a significant relationship between IPR protection and FDI. IPR protection is likely to influence not only the volume of FDI but also the quality of FDI (Lee \& Mansfield, 1996; Seyoum, 1996; Maskus, 1998; Smarzynska, 2004). Theses studies have not linked the effects of IPR on FDI to long run growth.

Seyoum (1996) finds that IPR protection is significant in explaining FDI. For a sample of 27 countries studied over the period 1975-1990, the author observed a positive effect of IPR protection on total FDI flows. However, this effect is not significant in developing countries. In contrast, Maskus (1998) finds that IPR protection has a positive impact on the FDI stock held by U.S. firms in the case of developing countries.

Lee and Mansfield (1996) show a positive correlation between the strengthening of IPR protection and the flow of inward FDI in a host country. The authors tested the relationship between the volume of U.S. outward FDI flows in 14 countries (mainly in South America countries and the South East Asian countries). They find that the coefficient on IPR protection is positive and statistically significant implying that strong protection can attract more FDI. In addition, they emphasize the existence of a link between IPR protection and composition of FDI. Their study shows that the technology intensity of FDI tends to increase the effectiveness of anti-counterfeiting legislation in the host country. This result is confirmed by the study of Smarzynska (2004) which showed a significant effect of weak IPR protection on the composition of FDI flows. It discourages foreign investment in sectors with high technological intensity.

Similarly, Park and Lippoldt (2008) show, other things being equal, that IPR significantly and positively influences the stock of direct investment received by developing countries. Their work, conducted for a panel of developing countries over the period 1990-2005 also shows that IPR attract foreign direct investments in technology-intensive sectors ( such as chemicals and machinery).

\section{Methodology}

\subsection{Empirical Strategy}

The model that we aim adopt comprises two equations that will be estimated simultaneously. The first equation explains the growth rate of TFP. The second equation shows the relationship between FDI and IPR protection. In the model, the IDE will be an endogenous variable in the second equation and appear as an exogenous variable in the first equation. IPR protection will be a common predictor for both equations. The empirical analysis uses a panel data set consisting of nine periods 1970-1974, 1975-1979, 1980-1984, 1985-1989, 1990-1994, 19951999, 2000-2004, 2005-2009 and 2010-2011. The model is estimated in a first time for a sample of seven Arab countries and Iran is added in a second stage. The sample of Arab countries including Egypt, Iraq, Jordan, Mauritania, Morocco, Saudi Arabia and Tunisia. The estimation period is 1970-2011. 


\section{Equation 1: Equation of TFP growth}

The first equation explains the growth rate of TFP. It is built from the growth models that estimated the effect of FDI (Borensztein et al., 1998). It is also enriched by models that introduce the effect of IPR protection (Park \& Ginarte, 1997, Gould \& Gruben, 1996).

It is assumed that FDI, human capital, IPR protection and the initial technological level are determining the rate of TFP growth of a developing country and that a developing country starts with a low level of technology. The initial technological gap between developed countries (source of direct investment) and the host country is large. Thanks to technology transfer through FDI, it is expected that the developing countries will grow at a faster rate, which would imply some form of convergence. However, this process of convergence is conditional, so that the growth rate depends, given an initial technological gap, on national policies and other variables that influence the growth rate of the host country. To test the convergence hypothesis, the majority of empirical studies introduce a measure of the initial situation in their growth regressions. Thus, the first equation can be written as follows:

$$
\text { GTFP }_{\text {it }}=\alpha_{0}+\alpha_{1} \log \left(\mathrm{y}_{0}\right)_{\text {it }}+\alpha_{2} \log (\text { ayss })_{\text {it }}+\alpha_{3} \log (\mathrm{IDE})_{\mathrm{it}}+\alpha_{4} \log D P I_{i t}+\varepsilon_{i t}
$$

with: i mean a country, $\mathrm{t}$ means the period of time; GTFP is the average growth rate of TFP of a country calculated on periods 1970-1974, 1975-1979, 1980-1984, 1985-1989, 1990-1994, 1995-1999, 2000-2004, 2005-2009 and 2010-2011. Log ( $\left.\mathrm{y}_{0}\right)$ is the logged level of per capita GDP at the begging of each period. Log (ayss) is the logarithm of average years of secondary schooling for people over 15 at the begging of each period. $\log$ (FDI) is the logarithm of the average ratio of net inflows of foreign direct investment in GDP. Log (IPR) is the logarithm of the Park and Ginarte indicator of IPR defined for the initial year of each period, $\varepsilon$ is an error term.

The first equation differs from the existing literature by estimating a growth regression where FDI and IPR protection are introduced simultaneously.

\section{Equation 2: Relationship between FDI and IPR}

The second equation explains the FDI IPR protection in the host country. It is built from models of Park and Lippoldt (2008) and Lee and Mansfield (1996). It is also assumed that the developing country' attractiveness of FDI depends on the level of its human capital and its economic stability. The latter manifests through inflation with an expected adverse effect.

This effect is the loss of competitiveness of the host country of FDI, thus discouraging foreign investors. In addition, civil liberty is assumed crucial in attracting FDI. The second equation is:

$$
\log (\mathrm{FDI})_{\mathrm{it}}=\beta_{0}+\beta_{1} \log (\text { IPR })_{i t}+\beta_{2} \log \left(\text { atys }_{i t}+\beta_{3} \text { civ.libe }_{\mathrm{it}}+\beta_{4} \text { inflation }_{i t}+\varepsilon_{\mathrm{it}}^{\prime}\right.
$$

where: i denotes a country and tenotes the time period, variables $\log$ (FDI) and log (IPR) have the same definitions as in Equation 1. Log (atys) is the logarithm of average years of total schooling for people over 15 at the begging of each period.

Civ.lib is the average of the indicator of civil liberty calculated on periods 1970-1974, 1975-1979, 1980-1984, 1985-1989, 1990-1994, 1995-1999, 2000-2004, 2005-2009. It's defined at the begging of period 2010-2011. Inflation is the average rate of inflation (measured by the GDP deflator). $\varepsilon$ ' is an error term.

We also consider an alternative specification in which we include freedom status in place of civil liberty. The third equation is:

$$
\log (\mathrm{FDI})_{\mathrm{it}}=\beta_{0}+\beta_{1} \log (\text { IPR })_{i t}+\beta_{2} \log (\text { atys })_{i t}+\beta_{3} \text { freedom }_{\mathrm{it}}+\beta_{4} \text { inflation }_{i t}+\varepsilon_{\mathrm{it}}^{\prime}
$$

Freedom is is the average of the indicator of freedom status calculated on periods $1970-1974,1975-1979,1980$ 1984, 1985-1989, 1990-1994, 1995-1999, 2000-2004, 2005-2009. It's defined at the begging of period 20102011. The indicator is the average of two variables « civil liberty» and "private property".

Finally, our model is written as follows:

$$
\left\{\begin{array}{l}
\text { GTFR }_{\mathrm{it}}=\alpha_{0}+\alpha_{1} \log \left(\mathrm{y}_{0}\right)_{\mathrm{it}}+\alpha_{2} \log (\text { ayss })_{\mathrm{it}}+\alpha_{3} \log (\mathrm{FDI})_{\mathrm{it}}+\alpha_{4} \log I P R_{i t}+\varepsilon_{i t} \\
\log (\mathrm{FDI})_{\mathrm{it}}=\beta_{0}+\beta_{1} \log (I \mathrm{PR})_{i t}+\beta_{2} \log (\text { atys })_{i t}+\beta_{3} \text { Civ.Lib }_{\mathrm{it}}\left(\text { freedom }_{i t}\right)+\beta_{4} \text { inflation }+\varepsilon_{\mathrm{it}}^{\prime}
\end{array}\right.
$$

Since all equations are over-identified, the model is over-identified. It is estimated by the method "Seemingly Unrelated Regressions (SUR)". 


\subsection{Data Sources}

Data on TFP and per capita GDP are from Feenstra, Robert C., Robert Inklaar and Marcel P. Timmer (2013), "The Next Generation of the Penn World Table". We use the index of patent rights developed by Park and Ginarte (The authors think Walter Park for providing updated data on the IPR index). This index is based on five categories of patent laws: extend of coverage, membership in international patent agreements, provisions for loss of protection, enforcement mechanisms and the duration of protection. Average years of secondary schooling for people over 15 and average years of total schooling for people over 15 are from Barro and Lee (2011). Data on ratio of net inflows of foreign direct investment in GDP and inflation was down from World's Bank's World Development indicators (2013). Data on civil liberties and freedom status are from Freedom House (Freedom in the World Country Ranking 1972-2011).

\subsection{Empirical Results}

Tables 1 and 2 show the results of estimating the model for the first sample (Arab countries) and for the second sample (Arab countries and Iran). In the last two regressions in Table 1, the variable civil liberty is replaced by the variable "freedom".

Note that the coefficients are elasticity that are interpreted as relative changes that provide information on the variation dependent variable following a unit change in the variable in question.

The results in Table 1 show that:

- The coefficient of initial GDP per capita is negative in all equations and statistically significant. Suggesting a convergence of the sample countries, that growth is accelerating away from the stationary state is slowing and in reasonable proximity thereto.

- The effect of human capital (average years of secondary schooling) on TFP growth has the expected positive sign and is statistically significant at the $1 \%$ level.

- Foreign direct investment has negative influence on the economic performance of these countries in most cases. This can be explained by the fact that the conditions inside the host country may appear predetermining both in the ability to attracting FDI with a chance to transform the specialization of the host country and the implementation mechanisms of overflow in the local production. Indeed, with, among others, inadequate basic infrastructure, a poorly qualified workforce, industries disarticulated, FDI only amplify the dependence of these countries to strangers.

- IPR positively influences economic growth in these countries, because its coefficient is always positive and statistically significant indicating a dominant effect on economic growth. This result is consistent with Gould and Gruben (1996)' work which reports a positive and significant effect of IPR protection on GDP growth using a measure of IPR protection based on that of Rapp and Rozek (1990).

Table 1. TFP growth regressions

\begin{tabular}{|c|c|c|c|c|}
\hline \multicolumn{5}{|c|}{ Dependent Variable TFP growth rate(1970-2011) } \\
\hline & Arab countries & $\begin{array}{l}\text { Arab countries } \\
\text { and Iran }\end{array}$ & Arab countries & $\begin{array}{c}\text { Arab countries } \\
\text { and Iran }\end{array}$ \\
\hline Variables Explicatives & (1) & $(2)$ & (3) & (4) \\
\hline $\log \left(\mathrm{y}_{0}\right)$ & $\begin{array}{c}-0.0266 * * * * \\
(-3.18)\end{array}$ & $\begin{array}{c}-0.0310^{* * *} \\
(-3.87)\end{array}$ & $\begin{array}{c}-0.0260 * * * \\
(-3.10)\end{array}$ & $\begin{array}{c}-0.0301 * * * \\
(-3.75)\end{array}$ \\
\hline Log (ayss) & $\begin{array}{c}0.0346^{* * * *} \\
(3.12)\end{array}$ & $\begin{array}{c}0.0320 * * * \\
(3.04)\end{array}$ & $\begin{array}{c}0.0338 * * * \\
(3.04)\end{array}$ & $\begin{array}{c}0.0311^{* * *} \\
(2.95)\end{array}$ \\
\hline $\log (\mathrm{FDI})$ & $\begin{array}{c}-0.0248 * * * \\
(-5.09)\end{array}$ & $\begin{array}{c}-0.0185 * * * \\
(-4.60)\end{array}$ & $\begin{array}{c}-0.0243 * * * \\
(-4.99)\end{array}$ & $\begin{array}{c}-0.0180 \div * * \\
(-4.47)\end{array}$ \\
\hline $\log (I P R)$ & $\begin{array}{c}0.0343 * * \\
(2.51)\end{array}$ & $\begin{array}{c}0.0282 * * \\
(2.04)\end{array}$ & $\begin{array}{c}0.0340 * * \\
(2.49)\end{array}$ & $\begin{array}{c}0.0279 * * \\
(2.02)\end{array}$ \\
\hline Constante & $\begin{array}{c}0.3099 * * * \\
(4.52)\end{array}$ & $\begin{array}{c}0.3173^{* * *} \\
(4.71)\end{array}$ & $\begin{array}{c}0.3031^{* *} \\
(4.41)\end{array}$ & $\begin{array}{c}0.3080^{* * *} \\
(4.57)\end{array}$ \\
\hline Chi2 & $42.58 * * *$ & $39.17 * * *$ & $40.83 * * *$ & $36.86 * * *$ \\
\hline $\mathrm{R}^{2}$ & 0.3886 & 0.3092 & 0.3860 & 0.3130 \\
\hline Observations & 50 & 56 & 50 & 56 \\
\hline
\end{tabular}

Note. t-statistics are in parentheses. $* * *, * *$ and $*$ indicate statistical significance at the $1 \%, 5 \%$ and $10 \%$ levels respectively. Estimation is by Seemingly Unrelated Regression. Equation in column $\mathrm{x}$ is jointly estimated with equation corresponding to column $\mathrm{x}$ 's of table 2, where $\mathrm{x}=1$, $2,3,4)$. 
Table 2. Relationship between FDI and IPR

\begin{tabular}{|c|c|c|c|c|}
\hline & \multicolumn{3}{|c|}{ Dependent Variable: FDI net inflows (\% GDP),1970-2011 } & \multirow[b]{2}{*}{$\begin{array}{c}\text { Arab countries } \\
\text { and Iran }\end{array}$} \\
\hline & Arab countries & $\begin{array}{l}\text { Arab countries } \\
\text { and Iran }\end{array}$ & Arab countries & \\
\hline Explicatives Variables & (1) & (2) & (3) & (4) \\
\hline $\log (\mathrm{IPR})$ & $\begin{array}{c}0.7483 * * \\
(2.15)\end{array}$ & $\begin{array}{c}0.7799 * * \\
(2.06)\end{array}$ & $\begin{array}{c}0.8927 * * \\
(2.52)\end{array}$ & $\begin{array}{c}0.9311 * * \\
(2.42)\end{array}$ \\
\hline $\log ($ atys $)$ & $\begin{array}{c}0.8920^{* * *} \\
(2.69)\end{array}$ & $\begin{array}{c}0.7218^{* *} \\
(2.12)\end{array}$ & $\begin{array}{c}0.8882 * * * \\
(2.58)\end{array}$ & $\begin{array}{c}0.7149 * * \\
(2.03)\end{array}$ \\
\hline Civ. lib & $\begin{array}{c}-0.5224 * * \\
(-2.47)\end{array}$ & $\begin{array}{c}-0.5565^{* *} \\
(-2.45)\end{array}$ & & \\
\hline Freedom & & & $\begin{array}{c}-0.3845^{*} \\
(-1.77)\end{array}$ & $\begin{array}{c}-0.4061 * \\
(-1.72)\end{array}$ \\
\hline inflation & $\begin{array}{l}-0.0287 \\
(-1.05)\end{array}$ & $\begin{array}{c}-0.0649 * * * \\
(-2.63)\end{array}$ & $\begin{array}{c}-0.0372 \\
(-1.35)\end{array}$ & $\begin{array}{c}-0.0780 * * * \\
(-3.25)\end{array}$ \\
\hline Constante & $\begin{array}{c}6.0682 * * * \\
(5.54)\end{array}$ & $\begin{array}{c}6.7289 * * * \\
(5.82)\end{array}$ & $\begin{array}{c}5.4348 * * * \\
(4.83)\end{array}$ & $\begin{array}{c}6.0626^{* * * *} \\
(5.05)\end{array}$ \\
\hline Chi2 & $25.39 * * *$ & $33.35 * * *$ & $21.36 * * *$ & $29.06^{* * *}$ \\
\hline $\mathrm{R}^{2}$ & 0.3189 & 0.3481 & 0.2845 & 0.3210 \\
\hline observations & 50 & 56 & 50 & 56 \\
\hline
\end{tabular}

Note. t-statistics are in parentheses. ${ }^{* *},{ }^{* *}$ et $*$ indicate statistical significance at the $1 \%, 5 \%$ and $10 \%$ levels respectively. Estimation is by Seemingly Unrelated Regression. jointly with TFP growth equation.

The results in Table 2 show that:

- The coefficients associated with the variable IPR are positive and statistically significant at the $5 \%$ level. Suggesting a positive effect of this variable on the net inflows of FDI in the countries of our samples. The results are supportive of the theory that IPR protection is a major factor attracting FDI inflows (Lai, 1998). They are also consistent with work by Maskus (1998) who finds that IPR protection has a positive impact on the FDI stock held by U.S. firms in the case of developing countries and work by Park and Lippoldt (2008) who find the IPR protection is an important determinant of the stock of direct investment received by developing countries.

- As expected, human capital (average years of total schooling) has positive and statistically significant effect on FDI inflows in all the regressions.

- The coefficients associated with the variable inflation are negative and statistically significant, because this variable is considered a measure of "financial repression", where most studies have shown its negative impact on economic growth and on national and international investment via its effect on profitability.

- The variables "civil liberties" and "Freedom Status" seem to be negatively correlated with FDI in these countries. This finding is not surprising because the countries of our samples are "partly free" or "Not free".

Result, which can find an explanation which states that on the one hand, the political institutions will have an indirect effect on economic growth, an effect that passes through investment and human capital in particular. On the other hand, a unwell political and institutional environment do not attracts foreign investors as it contributes to the fruitlessness of their projects, because the conditions inside the host country may appear predetermining both in the ability to attracting FDI with a chance to transform the specialization of the host country and the implementation mechanisms of overflow in the local production.

\section{Conclusion}

As part of this research, we tried to help resolve the fundamental question: What is the nature of the relationship between technology transfer through FDI and IPR protection in an Arab country?

To do this, we used a simultaneous equations model covering a sample of seven Arab countries and next a sample of Arab countries and Iran during the period 1970-2011.

The key findings emerged from this empirical analysis show:

- A positive effect exerted by the IPR on TFP growth.

- A positive effect exerted by the IPR on FDI. 
First, the results appear to confirm that IPR protection is a key determinant of PTF growth and it is consistent with the findings in Gould and Gruben (1996). Second, IPRs affect economic growth indirectly. This result is in accordance with the results in Park and Ginarte (1997) who have demonstrated that IPRs affect economic growth indirectly by stimulating the accumulation of factors of production such as physical capital and R\&D capital. Similarly the Xu and Chiang (2005)' study that has show that IPR protection affects economic growth indirectly by attracting flows of foreign patents. Third, IPR protection tends to attract more FDI inflows. This is consistent with early findings in other studies by Lee and Mansfield (1996); Maskus (1998) and Park and Lippoldt (2008).

In general, the results of these econometric studies consolidate the results already obtained by several researchers in this field.

We conclude, without confirming that these analyzes have allowed us, even in part, to show the existence of a relationship between IPR, FDI and economic performance. However, it is important to note that despite the importance of empirical results which leads this work, deficiencies may arise:

- Other possible mechanisms of the relationship under study were not considered.

- Lack of data made our sample small.

The relationship between IPR, FDI and economic performance could be better understood once its underlying mechanisms are still being analyzed and these shortcomings are remedied.

\section{References}

Balasubramanyam, V. N., Salisu, M., \& Dapsoford, D. (1996). Foreign direct investment and growth in EP and IS Countries. The Economic Journal, 106, 92-105. http://dx.doi.org/10.2307/2234933

Balasubramanyam, V. N., Salisu, M., \& Dapsoford, D. (1999). Foreign direct investment as an engine of growth. The Journal of International Trade \& Economic Development, 8(1), 27-40. http://dx.doi.org/10.1080/09638199900000003

Blomstrom, M., Lipsey, R. E., \& Zejan, M. (1994). What explains developing countries growth. Working paper 4132, National Bureau of Economic Research.

Borensztein, E., De Gregorios, J., \& Lee, J. W. (1998). How does foreign investment affect growth. Journal of International Economics, 45, 115-135. http://dx.doi.org/10.1016/S0022-1996(97)00033-0

De Mello, L. R. Jr. (1997). Foreign direct investment in developing countries and growth: A selective survey. The Journal of Development Studies, 34(1), 1-34. http://dx.doi.org/10.1080/00220389708422501

De Mello, L. R. Jr. (1999). Foreign direct investment-led growth: Evidence from time series and panel data. Oxford Economic Papers. http://dx.doi.org/10.1093/oep/51.1.133

Falvey, R., \& Foster, N. (2006). The role of intellectual property rights in technology transfer and economic growth: Theory and evidence. United Nations Industrial Development Organization Working Papers, UNIDO, Vienna.

Falvey, R., Foster, N., \& Greenway, D. (2006). Intellectual property rights and economic growth. Review of Development Economicsm, 10(4). http://dx.doi.org/10.1111/j.1467-9361.2006.00343.x

Gould, D. M., \& Gruben, W. C. (1996). The role of intellectual property rights in economic growth. Journal of Development Economics, 48(2), 323-350. http://dx.doi.org/10.1016/0304-3878(95)00039-9

Lai, E. L. C. (1998). International intellectual property rights and the rate of product innovation. Journal of Development Economics, 55, 133-153. http://dx.doi.org/10.1016/S0304-3878(97)00059-X

Lee, J. W. (2001). Education for technology readiness: Prospects for developing countries. Journal of Human Development, 2(1), 115-151. http://dx.doi.org/10.1080/14649880120050219

Lee, J. W., \& Mansfield, E. (1996). Intellectual property rights and U.S foreign direct investment. Review of Economics and Statistics, 78(2), 181-186. http://dx.doi.org/10.2307/2109919

Maskus, K. E. (1998). The international regulation of intellectual property. Weltwirtschaftliches Archiv, 134, 186-208. http://dx.doi.org/10.1007/BF02708092

Maskus, K. E. (2000). Intellectual property rights and foreign direct investment. Policy Discussion Paper no 0022, Centre for International Economic Studies, University of Adelaide. http://dx.doi.org/10.2139/ssrn.231122

Park, W. G. (2008). International patent protection: 1960-2005. Research Policy, 37(4), 761-766. 
http://dx.doi.org/10.1016/j.respol.2008.01.006

Park, W. G., \& Ginarte, J. C. (1997). Intellectual property rights and economic growth. Contemporary Economic Policy, 15(3), 51-61. http://dx.doi.org/10.1111/j.1465-7287.1997.tb00477.x

Park, W. G., \& Lippoldt, D. C. (2008). Technology transfer and the economic implications of the strengthening of intellectual property rights in developing countries. OECD Trade Policy Working Papers, 62, OECD Publishing, Paris. http://dx.doi.org/10.1787/244764462745

Seyoum, B. (1996). The impact of intellectual property rights on foreign direct investment. Columbia Journal of World Business, 31, 50-59. http://dx.doi.org/10.1016/S0022-5428(96)90006-X

Smarzynska, J. B. (2004). The composition of foreign direct investment and protection of intellectual property rights: Evidence from transition economies. European Economic Review, 48, 39-62. http://dx.doi.org/10.1016/S0014-2921(02)00257-X

Thompson, M. A., \& Rushing, F. W. (1996). An empirical analysis of the impact of patent protection on economic growth. Journal of Economic Development, 21(2), 61-79.

$\mathrm{Xu}$, B. (2000). Multinational enterprises, technology diffusion, and host country productivity growth. Journal of Development Economics, 62, 477-493. http://dx.doi.org/10.1016/S0304-3878(00)00093-6

Xu, B., \& Chiang, E. P. (2005). Trade, patents and international technology diffusion. Journal of International Trade and Economic Development, 14(1), 115-135. http://dx.doi.org/10.1080/0963819042000333270

\section{Copyrights}

Copyright for this article is retained by the author(s), with first publication rights granted to the journal.

This is an open-access article distributed under the terms and conditions of the Creative Commons Attribution license (http://creativecommons.org/licenses/by/3.0/). 